\title{
Composição química e degradabilidade in situ da ração em ovinos em área de caatinga no sertão de Pernambuco ${ }^{1}$
}

\section{Gladston Rafael de Arruda Santos ${ }^{2}$, Ângela Maria Vieira Batista ${ }^{3}$, Adriana Guim ${ }^{3}$, Mércia Virginia Ferreira dos Santos ${ }^{3}$, Daniele Silva de Matos $^{4}$, Kleber Régis Santoro ${ }^{5}$}

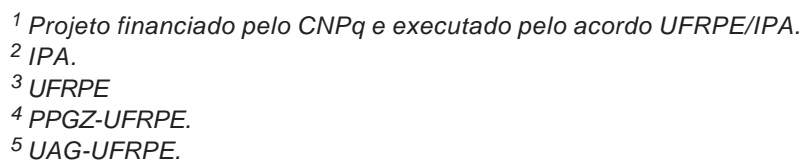

RESUMO - Objetivou-se avaliar o efeito do tipo de fístula e da hora de coleta sobre a composição química e a degradabilidade in situ da ração em ovinos criados na caatinga. Foram utilizados dez ovinos mestiços de Santa Inês (cinco com cânula no rúmen e cinco com cânula no esôfago) recebendo água e mistura mineral ad libitum. Os percentuais de matéria seca (MS) variaram de 11,99 a 25,28\%, matéria mineral (MM), 10,92 a 14,44\%, proteína bruta (PB), 10,64 a 17,19\%, extrato etéreo (EE), 2,95 a 4,77\%, fibra em detergente neutro (FDN), 54,83 a 63,14\%, fibra em detergente ácido (FDA), 39,40 a 46,62\%, proteína insolúvel em detergente neutro (PIDN), 49,74 a 57,95\%, proteína insolúvel em detergente ácido (PIDA), 28,52 a 39,15\%, carboidratos totais (CT), 65,40 a 72,73\%, carboidratos não-fibrosos (CNF), 5,47 a 12,86\%, fenóis totais (FT), 0,37 a 0,52\%, taninos totais (TT), 0,16 a $0,28 \%$ e taninos condensados (TC), 1,28 a $6,24 \%$, respectivamente. A degradabilidade potencial variou de 48,25 a 64,63\% para MS; 36,43 a 54,34\% para FDN; e de 62,13 a 77,24\% para proteína; a fração B, de 35,77 a 47,78\% para MS; 33,28 a 50,38\% para FDN; e 35,44 a 56,09\% para proteína; a fração C, de 4,60 a 13,40\% para MS; 3,84 a 8,42\% para FDN; e 5,37 a 14,36\% para proteína; a fração A, 9,74 a 18,13\% para MS; 2,16 a 4,41\% para FDN; e 20,21 a 31,49\% para proteína; a degradabilidade efetiva para a taxa de passagem de 2\%/hora, de 43,28 a 55,71 para MS; 29,21 a 36,54 para FDN; 55,84 a 67,49 para proteína; e a degradabilidade efetiva para a taxa de passagem de 5\%/hora, de 37,60 a 47,27 para MS; 23,02 a 33,33 para FDN; e 45,74 a 59,99 para proteína. A composição química e a degradabilidade in situ da ração em ovinos foi influenciada pelo mês de avaliação. A dieta apresentou baixa digestibilidade in situ da MS, FDN e PB. A fistula ruminal, em comparação à fistula de esôfago, permitiu melhor avaliação da dieta, em virtude da recuperação total da extrusa.

Palavras-chave: degradabilidade, FDN, forrageiras nativas, matéria seca, PB

\section{Chemical composition and in situ digestibility of diets for sheep in the caatinga region}

\begin{abstract}
This work was conducted with the objective of evaluating the effect of the type of fistula and time of collection on the chemical composition and in situ digestibility of dry matter, neutral detergent fiber and crude protein in the caatinga region. The experiment was conducted between September 2004 and July 2005. Ten Santa Inês castrated sheep, five with permanent ruminal cannula and five with esophageal cannula, were used. Samples were collected from both cannulas at 7:00 am and 2:00 pm. Sheep had free access to water and mineral mix. The percentage of DM, MM, CP, EE, NDF, ADF, NDIP, ADIP, CHOT, NFC, FT, TT and TC ranged from 11.99 to $25.28 \%$; 10.92 to $14.44 ; 10.64$ to $17.19 \%$; 2.95 to $4.77 ; 54.83$ to $63.14 \%$; 39.40 to $46.62 \%$; 49.74 to $57.95 ; 28.52$ to $39.15 ; 65.40$ to $72.73 ; 5.47$ to $12.86 \%$; 0.37 to $0.52 \%$; 0.16 to $0.28 \%$; and from 1.28 to $6.24 \%$, respectively. Potential degradability (\%), fraction B (\%), fraction C (\%/h), fraction A (\%), effective degradability and passage rate of 2 and 5\%/h ranged from 48.25 to 64.63 ; 35.77 to 47.78 ; 4.60 to 13.40 ; 9.74 to 18.13 ; 43.28 to 55.71 and 37.60 to 47.27 for dry matter; from 36.43 to 54.34 ; 33.28 to 50.38 ; 3.84 to 8.42 ; 2.16 to $4.41 ; 29.21$ to $36.54 ; 23.02$ to 33.33 for neutral detergent fiber and from 62.13 to $77.24 ; 35.44$ to 56.09 ; 5.37 to 14.36; 20.21 to 31.49 ; 55.84 to $67.49 ; 45.74$ to 59.99 for protein, respectively. The chemical composition and in situ digestibilility of diets for sheep in caatinga is influenced by the month of evaluation. The diet for sheep in the caatinga region presented low in situ digestibility of dry matter, neutral detergent fiber and crude protein. Ruminal cannula instead of esophageal cannula can be used to characterize the chemical composition and degradability of diet consumed by small ruminants.
\end{abstract}

Key Words: crude protein, degradability, dry matter, native forage, neutral detergent fiber 


\section{Introdução}

Não são poucas as iniciativas de identificação e descrição das principais espécies forrageiras nativas do semiárido nordestino (Sampaio, 2005). Também existe razoável quantidade de trabalhos sobre a composição químicobromatológica de várias espécies, entretanto, trabalhos realizados em área de caatinga para avaliação da utilização de fístula ruminal para coleta de extrusa e do horário de coleta dessa extrusa são escassos.

As plantas da caatinga possuem mecanismos fisiológicos e morfológicos de defesa contra as condições adversas do ambiente e ataques microbiano e de insetos. Um destes mecanismos de defesa é a presença de compostos secundários, que podem ser tóxicos aos animais, além de possuírem fatores antinutricionais. Os resultados de trabalhos avaliando dietas ricas em taninos sobre os microrganismos ruminais têm sido divergentes (Beelen et al., 2006), em virtude das variações na estrutura molecular dos taninos (peso molecular, composição monomérica).

Os coeficientes de digestibilidade de forrageiras nativas in vivo, in situ e in vitro determinados em caprinos e ovinos, são em geral medianos (Vasconcelos et al., 1997; Araújo Filho et al., 2002; Gonzaga Neto, 1999; Gonzaga Neto et al., 2001). Entretanto, o desempenho desses animais, quando em pastejo, parece indicar valores de digestibilidade maiores. Forrageiras arbóreas e arbustivas geralmente apresentam coeficientes de digestibilidade inferiores aos encontrados para herbáceas e gramíneas. Isto se deve, provavelmente, às mais elevadas concentrações de lignina e aos compostos secundários contidos nestas categorias. A presença dessas substâncias pode resultar em diferentes interrelações; por exemplo, jurema-preta e catingueira afetam negativamente a digestibilidade in vitro e in vivo da ração (Carvalho Filho \& Salviano, 1982; Gonzaga Neto, 1999), quando fornecidos na forma de feno.

O objetivo neste trabalho foi determinar a composição química e a degradabilidade da dieta, considerando o local da fístula (esôfago ou rúmen) e a hora de coleta (manhã e tarde), em ovinos mantidos na caatinga do Sertão de Pernambuco.

\section{Material e Métodos}

A pesquisa foi realizada em área de 37 ha, de setembro de 2004 a julho de 2005 na Estação Experimental de Sertânia, pertencente à Empresa Pernambucana de Pesquisa Agropecuária - IPA, localizada no município de Sertânia, a uma latitude $08^{\circ} 04^{\prime} 25^{\prime \prime}$ sul e a uma longitude $37^{\circ} 15^{\prime} 52^{\prime \prime}$ oeste, na microrregião do Moxotó a 600 m acima do nível do mar, em ecossistema de caatinga, com clima semi-árido quente, temperatura anual média de $25^{\circ} \mathrm{C}$, precipitação acumulada no período de avaliação de $520 \mathrm{~mm}$, em que março a junho são os principais meses chuvosos (dados coletados na estação).

As colheitas de extrusa para determinação da composição química da dieta foram realizadas de setembro/2004 a julho/2005: três avaliações no período seco (setembro, novembro, janeiro) e três no período chuvoso (março, maio, julho). Para determinação da degradabilidade in situ da ração, foram realizadas colheitas de novembro/2004 a julho/ 2005. Na colheita da extrusa para determinação da composição química e degradabilidade da forragem selecionada pelos animais em cada período de colheita, foram usados dez ovinos mestiços de Santa Inês, castrados, cinco com cânulas permanentes no rúmen e cinco no esôfago, com peso médio inicial de $25 \mathrm{~kg}$. Os animais foram mantidos na área experimental durante todo o ano, sem suplementação, recebendo água e mistura mineral à vontade.

As colheitas de extrusa foram divididas entre os turnos da manhã ( 8 h) e da tarde ( 14 h), em dias alternados, visando reduzir o efeito do manejo da colheita de extrusa sobre o comportamento de consumo dos animais.

Nas colheitas realizadas pela manhã, os animais eram mantidos em jejum prévio de 15 horas antes do acesso ao pasto. Nos animais fistulados no esôfago, a cânula foi retirada e uma bolsa coletora confeccionada em lona impermeável, com tela de náilon ao fundo, foi acoplada para saída do excesso de saliva. Nos animais fistulados no rúmen, todo conteúdo ruminal era removido e armazenado em baldes, independentemente do horário de coleta, devidamente identificado por animal e recolocado no rúmen após a coleta da extrusa. Em seguida, os animais eram soltos na área experimental por 1 hora. Após este período, eram recolhidos e a extrusa coletada, identificada por período, animal e hora de coleta, sendo armazenada para posteriores análises. Nas coletas da tarde, os animais eram recolhidos da caatinga, imediatamente antes da coleta, preparados como descrito anteriormente, e soltos na área experimental.

A composição química da extrusa foi analisada no Laboratório de Nutrição Animal da UFRPE para determinação dos teores de matéria seca (MS), matéria orgânica (MO), proteína bruta (PB) e extrato etéreo (EE), segundo metodologias descritas por Silva e Queiroz (2002). As determinações da fibra em detergente neutro (FDN) e fibra em detergenteácido (FDA) foram feitas em aparelho ANKON Techhnology ${ }^{\circledR}$, utilizando-se metodologia descrita por Van Soest et al. (1991). Na determinação da proteína insolúvel em detergente neutro (PIDN) e proteína insolúvel 
em detergente ácido (PIDA) foi empregada metodologia descrita por Licitra et al. (1996). Os teores de carboidratos totais $(\mathrm{CT}=100-(\mathrm{PB}+\mathrm{EE}+\mathrm{MM}))$ foram estimados segundo Sniffen et al., (1992) e os teores de carboidratos nãofibrosos $(\mathrm{CNF}=100-(\% \mathrm{~PB}+(\mathrm{FDN}-\mathrm{PIDN}-\mathrm{CIDN})+\% \mathrm{EE}$ $+\% \mathrm{MM})$ ) foram obtidos como sugerido por Hall (2001), com modificação quanto à correção para cinzas no FDN. As análises referentes aos teores de fenóis totais (FT), taninos totais (TT) e taninos condensados.(TC) foram realizadas de acordo com metodologia descrita por FAO/IAEA(FAO, 2000).

A degradabilidade in situ foi determinada nas amostras da extrusa coletadas dos animais com fístula esofágica ou ruminal. As amostras foram pré-secas em estufa de ventilação forçada por 72 horas a temperatura de $45^{\circ} \mathrm{C}$ e trituradas em moinho de faca a $5 \mathrm{~mm}$, mantendo-se a individualidade das amostras, isto é, as amostras foram separadas por período de coleta, tipo de fístula e horário de coleta.

Para a incubação, parte da amostra $(1,5 \mathrm{~g})$ foi pesada em duplicata em sacos de náilon, medindo $10 \times 5 \mathrm{~cm}$, com porosidade de 50 micras, previamente pesados e identificados. Utilizaram-se pequenas sacolas feitas com tecido em forma de malha para acondicionar os sacos com as amostras para incubação, bem como um peso para manter o material submerso no rúmen. Essas sacolas estavam fixadas a um cordão de náilon com tamanho suficiente para que o material atingisse a região ventral do rúmen.

$\mathrm{O}$ ensaio de degradabilidade in situ foi realizado utilizando-se os mesmos ovinos fistulados no rúmen. Cada animal recebeu sua própria amostra de extrusa e uma proveniente da fístula esofágica, de modo que cada animal recebia um par de amostras (uma de rúmen e outra de esôfago por tempo de incubação).

Os tempos de incubação estabelecidos foram: $0,3,6,12$, 24, 48, 72 e 96 horas. Os sacos foram inseridos em horários decrescentes, de modo a serem removidos simultaneamente para reduzir a interferência da excessiva manipulação sobre o ambiente ruminal. As amostras correspondentes a hora zero não foram colocadas no rúmen, porém foram lavadas junto com o material retirado após incubação.

Após a remoção, as sacolas foram lavadas em água corrente para retirada do excesso de conteúdo ruminal. Em seguida, os sacos foram retirados, colocados em máquina de lavar compacta, com intervalos de lavagem de 1 minuto, retirando-se a água depois de cada lavagem, até que a mesma estivesse clara. Depois de lavados, os sacos foram colocados em estufa com ventilação forçada, a $55^{\circ} \mathrm{C}$ durante 72 horas, para pré-secagem. Após serem retirados da estufa, os sacos foram colocados em dessecador durante 1 hora para pesagem em balança analítica.
As análises químicas do resíduo da incubação foram realizadas no Laboratório de Nutrição Animal/DZ/UFRPE para determinação dos teores de matéria seca (MS) e proteína bruta (PB), segundo metodologias descritas por Silva e Queiroz (2002), e fibra em detergente neutro (FDN), em aparelho ANKON Techhnology ${ }^{\circledR}$, utilizando-se metodologia descrita por Van Soest et al. (1991).

O modelo proposto por Orskov e McDonald (1979) foi utilizado para determinação da degradabilidade potencial e efetiva da MS, PB e FDN com as fórmulas:

$\mathrm{p}=\mathrm{a}+\mathrm{b}\left(1-\mathrm{e}^{-\mathrm{ct}}\right)$ em que: $\mathrm{p}=$ degradabilidade potencial; $\mathrm{a}=$ fração solúvel em água; $\mathrm{b}$ = fração potencialmente degradada; c = taxa constante de degradação da fração b; $\mathrm{t}$ = tempo de incubação e,

Dge $=\mathrm{a}+\underline{\mathrm{bxc}}$, em que:

$$
\mathrm{c}+\mathrm{k}
$$

Dge = degradabilidade efetiva; $\mathrm{k}=$ taxa de passagem de sólidos no rúmen de 2 e $5 \% / h o r a$, que pode ser atribuído a níveis de consumo alimentar baixo e médio, conforme AFRC (1993).

O delineamento experimental utilizado foi inteiramente casualizado, em um arranjo fatorial $6 \times 2 \times 2$ (meses de coleta $(\mathrm{M}) \times$ tipos de fístula $(\mathrm{F}) \times$ hora de coleta $(\mathrm{H})$ ). Os dados obtidos foram submetidos à análise de variância e as médias, comparadas pelo teste Tukey $(\mathrm{P}<0,05)$ utilizando-se o PROC GLM (SAS, 2004).

\section{Resultados e Discussão}

Houve efeito do período de coleta $(\mathrm{P}<0,05)$ sobre a composição química da extrusa dos ovinos, exceto sobre o percentual de fenóis totais (FT) (Tabela 1), possivelmente em virtude da variação no estadio fenológico das plantas e nas frações da planta disponíveis para os animais (folha, caule, flor, fruto ou semente). Ressalta-se que a seletividade pelos ovinos acarretou diferença na composição botânica e, conseqüentemente, na composição química da dieta.

As principais variações na composição química da dieta referem-se aos teores de PB, FDN e taninos condensados (Tabela 1). O teor de PB variou de 10,6\% em setembro/2004 a 17,2\% em março/2005, o que está associado à rebrota das plantas e à disponibilidade de material mais jovem no mês de março, período com maior precipitação pluviométrica (Santos, 2007). A menor variação nos teores de FDN ocorreu entre os períodos de avaliação, com média em torno de $60 \%$, exceto no mês de março, que foi de $54,8 \%$.

Araújo Filho et al. (1996), avaliando a composição química da dieta de ovinos e caprinos em pastoreio combinado, observaram que os ovinos apresentaram na sua dieta 13,4; 8,5 e 16,5\% de proteína; e 52,4; 58,7 e 55,3 \% de FDN 
Tabela 1 - Composição química da dieta de ovinos pastejando na caatinga em diversos períodos de coleta

\begin{tabular}{|c|c|c|c|c|c|c|}
\hline \multirow[t]{2}{*}{ Composição } & \multicolumn{3}{|c|}{ Período seco } & \multicolumn{3}{|c|}{ Período chuvoso } \\
\hline & Setembro & Novembro & Janeiro & Março & Maio & Julho \\
\hline Matéria seca (\%) & $22,64 \pm 3,10 b$ & $25,28 \pm 2,52 a$ & $20,41 \pm 2,53 b$ & $17,53 \pm 3,09 c$ & $11,99 \pm 2,07 d$ & $14,17 \pm 3,01 \mathrm{~d}$ \\
\hline Matéria orgânica & $88,34 \pm 1,64 a$ & $87,42 \pm 1,44 a b$ & $89,00 \pm 0,78 a$ & $85,92 \pm 1,14 b$ & $85,55 \pm 1,98 b$ & $89,07 \pm 3,16 a$ \\
\hline Cinzas & $11,65 \pm 1,64 b$ & $12,58 \pm 1,44 a b$ & $10,99 \pm 0,78 b$ & $14,07 \pm 1,14 \mathrm{a}$ & $14,44 \pm 1,98 a$ & $10,92 \pm 3,16 b$ \\
\hline Proteína bruta & $13,30 \pm 1,50 \mathrm{~b}$ & $10,64 \pm 0,93 c$ & $13,36 \pm 1,22 b$ & $14,43 \pm 1,54 \mathrm{~b}$ & $17,19 \pm 2,44 a$ & $16,61 \pm 2,09 \mathrm{a}$ \\
\hline Extrato etéreo & $3,03 \pm 0,53 b$ & $4,03 \pm 1,37 \mathrm{ab}$ & $4,77 \pm 0,88 a$ & $3,79 \pm 1,74 \mathrm{ab}$ & $2,95 \pm 0,46 b$ & $3,35 \pm 0,57 b$ \\
\hline Fibra em detergente neutro & $62,02 \pm 4,21 \mathrm{a}$ & $62,23 \pm 4,39 a$ & $61,10 \pm 3,65 a$ & $54,83 \pm 6,19 b$ & $60,40 \pm 3,75 a$ & $63,14 \pm 3,64 a$ \\
\hline Fibra em detergente ácido & $46,62 \pm 3,57 a$ & $45,60 \pm 2,62 \mathrm{a}$ & $44,35 \pm 4,71 \mathrm{ab}$ & $39,98 \pm 5,10 b$ & $42,63 \pm 4,89 a b$ & $39,40 \pm 6,83 b$ \\
\hline PIDN $^{1}$ & $57,95 \pm 5,99 a b$ & $53,20 \pm 4,48 b c$ & $50,73 \pm 5,29 c$ & $49,74 \pm 5,84 c$ & $59,76 \pm 5,03 a$ & $59,06 \pm 5,45 a$ \\
\hline $\mathrm{PIDA}^{2}$ & $39,15 \pm 8,32 \mathrm{a}$ & $34,39 \pm 5,96 a b$ & $31,66 \pm 5,70 \mathrm{ab}$ & $28,52 \pm 6,14 b$ & $31,38 \pm 8,23 a b$ & $30,01 \pm 6,96 b$ \\
\hline Carboidratos totais & $72,00 \pm 2,00 \mathrm{ab}$ & $72,73 \pm 2,29 a$ & $70,86 \pm 1,57 \mathrm{abc}$ & $67,69 \pm 2,14 \mathrm{~cd}$ & $65,40 \pm 2,61 \mathrm{~d}$ & $69,10 \pm 5,46 b c$ \\
\hline Carboidratos não-fibrosos & $9,97 \pm 4,21 \mathrm{abc}$ & $11,51 \pm 4,81 \mathrm{ab}$ & $9,84 \pm 3,41 \mathrm{abc}$ & $12,86 \pm 6,26 a$ & $5,47 \pm 3,40 \mathrm{c}$ & $5,96 \pm 6,14 \mathrm{c}$ \\
\hline Fenóis totais & $0,37 \pm 0,09 a$ & $0,50 \pm 0,17 a$ & $0,47 \pm 0,18 \mathrm{a}$ & $0,52 \pm 0,17 a$ & $0,46 \pm 0,16 \mathrm{a}$ & $0,39 \pm 0,08 a$ \\
\hline Taninos totais & $0,25 \pm 0,04 a$ & $0,28 \pm 0,05 a$ & $0,26 \pm 0,09 a$ & $0,16 \pm 0,05 b$ & $0,26 \pm 0,08 \mathrm{a}$ & $0,23 \pm 0,09 a b$ \\
\hline Taninos condensados & $1,28 \pm 0,9 b$ & $3,17 \pm 0,97 a b$ & $5,19 \pm 3,39 a$ & $4,62 \pm 2,92 a$ & $3,68 \pm 1,53 \mathrm{ab}$ & $6,24 \pm 3,99 a$ \\
\hline
\end{tabular}

${ }^{1}$ Proteína insolúvel em detergente neutro; ${ }^{2}$ proteína insolúvel em detergente ácido; Médias seguidas pela mesma letra na linha não diferem (P>0,05) entre si pelo teste Tukey.

nos períodos de transição da estação úmida-seca, estação seca e na transição da estação seca-úmida, respectivamente.

Vasconcelos et al. (1996) observaram decréscimo no teor de proteína bruta do pasto durante a transição da estação chuvosa para a seca, quando ocorreu comportamento inverso ao das concentrações de FDN e lignina. Pimentel et al. (1992), trabalhando com ovinos na caatinga, observaram valores de 18,4 a 8,9\% de PB; 58,55 a 42,1\% de FDN; e 57,3 a 30,1\% de DIVMO ao longo do ano.

Os maiores valores de tanino condensados (TC) na forragem foram observados durantes os meses de janeiro e julho (5,19 e 6,24\%, respectivamente), o que provavelmente está associado à variação da composição botânica da dieta (Santos, 2007).

Lima et al. (1987), avaliando forrageiras nativas em área de caatinga no sertão de Pernambuco utilizando novilhos fistulados no esôfago, observaram que, em média, as dietas continham $17,4 \%$ de proteína bruta a mais que o pasto, aumento que pode estar relacionado à participação da leguminosa Bauhinia cheillantha Steud., do arbusto Cordia leucocephala Moric. e de poáceas, para a época chuvosa. Na época seca, no entanto, estaria relacionado à participação dos arbustos e da leguminosa Bauhinia cheillantha Steud.

Araújo Filho et al. (2002) estudaram a fenologia e o valor nutritivo de espécies lenhosas caducifólias da Caatinga, consideradas importantes para dietas de ruminantes, e verificaram variações na composição bromatológica e digestibilidade in vitro ao longo do ciclo fenológico, com os melhores índices alcançados pela vegetação plena, que coincidiu também com a maior disponibilidade de fitomassa. A Caesalpinia pyramidalis Tul e o Herisanthia tiubae K.Schum. Bri destacaram-se como as forrageiras de melhor potencial, pois mantiveram, durante o ciclo fenológico, os teores mais elevados de proteína bruta e digestibilidade. As folhas verdes de sabiá, conhecidamente de boa aceitabilidade, apresentaram teores de tanino próximos aos encontrados para o Herisanthia tiubae K.Schum. Bri em vegetação plena.

Na comparação entre fístulas, observou-se efeito significativo $(\mathrm{P}<0,05)$ sobre os teores de MS, MO, FDN, FDA e $\mathrm{MM}$, o que pode estar relacionado à diferença na recuperação da extrusa das fístulas utilizadas.

A fístula ruminal proporciona recuperação total da amostra de extrusa, enquanto, com a fístula esofágica, ocorreu recuperação incompleta, uma vez que o tamanho da fístula é insuficiente para passagem de algumas partes da planta ingeridas pelo animal, como folhas maiores ou partes de caules, principalmente de espécies arbustivas. Esse resultado foi evidenciado pelos maiores valores de MS, MO, FDN e FDA na extrusa coletada via rúmen. O teor de MM foi maior na extrusa colhida via fístula esofágica, possivelmente em razão da maior concentração de saliva, que, por ser rica em minerais, pode ter contribuído para o aumento deste composto.

Ressalta-se ainda que, dependendo das características físicas das plantas, pode haver formação de pequenos bolos alimentares que são deglutidos pelo animal e não caem na bolsa coletora, resultando então em possíveis falhas na determinação correta da composição química da dieta selecionada.

O horário de coleta influenciou $(\mathrm{P}<0,05)$ os teores de matéria seca, matéria orgânica e matéria mineral da extrusa o que pode ser relacionado, ao efeito do jejum provocado no animal quando a colheita foi feita pela manhã, o que proporciona maior avidez ao consumo quando o animal era 
solto na área e tem como conseqüência maior produção de saliva e contaminação da amostra.

Nas amostras obtidas no período da manhã, os animais haviam passado por jejum, desta forma, a possibilidade de contaminação da amostra por material ruminado é muito pequena, principalmente nos animais que possuíam cânula ruminal, em virtude do esvaziamento realizado antes da coleta da amostra. Entretanto, nas coleta realizadas à tarde, observou-se que, nos animais com fístula esofágica, ocorria pequena participação de material ruminado, o que pode ser considerado ponto negativo na utilização desse tipo de fístula para coleta de amostras de extrusa sem que os animais tenham passado por jejum prévio.

Houve interação período de coleta $\times$ tipo de fístula $(\mathrm{P}<0,05)$ para o teor de MS e PIDN (\%PB), provavelmente em decorrência dos efeitos desses fatores isoladamente. Houve também interação meses do ano $\times$ hora de coleta $(\mathrm{P}<0,05)$ para os teores de FDN, FDA, PIDN (\%PB) e CNF. Em virtude da variação na composição química e na disponibilidade de forragem ao longo do período experimental, os animais passaram a se adaptar a esta situação, tentando expressar ao máximo seu poder de seleção sobre a fitomassa existente na pastagem, objetivando selecionar dieta de melhor qualidade para atendimento de suas necessidades.

Os teores de matéria seca, matéria orgânica e matéria mineral foram influenciados $(\mathrm{P}<0,05)$ pela interação tipo de fístula $\times$ hora de colheita. Esse comportamento pode estar associado à porcentagem de recuperação da extrusa e à contaminação pela saliva ou pelo material oriundo do rúmem quando do processo de regurgitação e varia conforme o tipo de fístula e a seletividade do animal, que podem ser afetados pelo período de jejum.

Provavelmente, as variações na composição química da extrusa nos diferentes períodos de avaliação resultaram em diferenças na degradabilidade potencial e efetiva da MS, PB e FDN da dieta selecionada pelos ovinos (Tabelas $2,3,4)$
O período de avaliação influenciou $(\mathrm{P}<0,05)$ todas as variáveis relacionadas à degradabilidade potencial e efetiva da matéria seca (Tabela 2). Esse comportamento está diretamente relacionado à variação nos teores dos nutrientes da forragem ao longo do ano (Tabela 1 ), visto que a matéria seca é composta por estes nutrientes.

Houve interação significativa $(\mathrm{P}<0,05)$ período $\times$ hora de coleta sobre a degradabilidade potencial, a fração $C$, a fração A e a degradabilidade efetiva da matéria seca. Este comportamento acompanha o do teor de matéria seca (Tabela 1) e pode ser explicado pela variação das frações da planta selecionadas pelos animais ao longo do período experimental, tanto no horário da manhã como no da tarde.

Batista \& Mattos (2004) atribuíram a redução na digestibilidade da dieta dos ruminantes em área de caatinga à maior participação de caules e folhas de plantas lenhosas, mais ricas em compostos secundários, que contribuem para esta redução.

Houve interação significativa tipo de fístula $\times$ hora de coleta $(\mathrm{P}<0,05)$ sobre a degradabilidade potencial e a fração B da matéria seca.

Dornelas (2003) encontrou para a degradabilidade potencial, a fração B, a C, a A e a degradabilidade efetiva a 2 e 5\%/hora da MS, em caprinos alimentados com fenos de jureminha e feijão-bravo, valores de 69,53 e 49,34\%; 50,01 e 23,29\%; 5,11 e 4,42\%/hora; 19,53 e 26,05\%; 53,75 e 41,83\%; 43,27 e 36,78\%, respectivamente.

Van Soest (1994) reportou altas correlações negativas entre fibra em detergente ácido e lignina com digestibilidade da matéria seca e orgânica de várias gramíneas e leguminosas forrageiras. Marques \& Batista (1998) observaram degradabilidade potencial e taxa de degradação da MS e da PB para a forrageira sabiá de 53,82\% e 0,057 e 57,21\% e 0,023 , respectivamente.

Moreira et al. (2006), analisando a extrusa colhida em bovinos fistulados no esôfago, mantidos sob pastejo em

Tabela 2 - Degradabilidade da matéria seca da dieta de ovinos em pastejo na caatinga no sertão de Pernambuco em divesos meses de coleta

\begin{tabular}{|c|c|c|c|c|c|}
\hline \multirow[t]{2}{*}{ Parâmetro } & \multicolumn{5}{|c|}{ Mês } \\
\hline & Novembro & Janeiro & Março & Maio & Julho \\
\hline DP (\%) & $48,65 \pm 6,69 c$ & $52,41 \pm 6,39 c$ & $64,63 \pm 7,06 a$ & $63,76 \pm 8,66 a b$ & $55,87 \pm 9,98 \mathrm{bc}$ \\
\hline B (\%) & $38,90 \pm 4,04 b c$ & $35,77 \pm 5,19 c$ & $47,78 \pm 3,41 \mathrm{a}$ & $45,63 \pm 8,50 b$ & $40,39 \pm 7,52 b c$ \\
\hline C (\%/hora) & $13,40 \pm 3,76 a$ & $8,24 \pm 1,46 b$ & $8,93 \pm 1,63 b$ & $4,60 \pm 1,81 c$ & $7,12 \pm 1,65 b c$ \\
\hline A (\%) & $9,74 \pm 3,60 b$ & $16,63 \pm 5,13 a$ & $16,84 \pm 4,78 a$ & $18,13 \pm 4,18 \mathrm{a}$ & $15,43 \pm 3,53 a$ \\
\hline $\mathrm{DE}_{2}(\%)$ & $43,28 \pm 5,38 b$ & $45,24 \pm 6,17 b$ & $55,71 \pm 7,45 a$ & $48,73 \pm 7,57 a b$ & $48,82 \pm 9,38 b$ \\
\hline $\mathrm{DE}_{5}(\%)$ & $37,60 \pm 4,33 b$ & $38,68 \pm 6,01 b$ & $47,27 \pm 7,49 a$ & $39,03 \pm 7,05 b$ & $39,05 \pm 8,55 b$ \\
\hline
\end{tabular}

Médias seguidas pela mesma letra na linha não diferem $(\mathrm{P}>0,05)$ entre si pelo teste Tukey; DP - degradabilidade potencial; B - fração potencialmente degradável; C - taxa de degradação da fração potencialmente degradável; A - fração solúvel; $\mathrm{DE}_{2}$ - degradabilidade efetiva para as taxas de passagem de $2 \% /$ hora; $\mathrm{DE} \mathrm{E}_{5}$ - degradabilidade efetiva para as taxas de passagem de $5 \% /$ hora. 
Tabela 3 - Degradabilidade da fibra em detergente neutro da dieta de ovinos em pastejo na caatinga no sertão de Pernambuco em diversos meses de coleta

\begin{tabular}{|c|c|c|c|c|c|}
\hline \multirow[t]{2}{*}{ Parâmetro } & \multicolumn{5}{|c|}{ Mês } \\
\hline & Novembro & Janeiro & Março & Maio & Julho \\
\hline DP (\%) & $36,43 \pm 7,24 \mathrm{c}$ & $39,28 \pm 5,10$ bc & $51,44 \pm 7,57 a$ & $54,34 \pm 9,51 a$ & $47,83 \pm 8,67 a b$ \\
\hline B (\%) & $33,28 \pm 7,13 b$ & $36,99 \pm 5,21 b$ & $47,03 \pm 5,61 \mathrm{a}$ & $50,38 \pm 8,80 a$ & $45,67 \pm 8,31 \mathrm{a}$ \\
\hline C (\%/hora) & $8,02 \pm 4,31 a$ & $6,81 \pm 1,45 a b$ & $8,42 \pm 2,78 a$ & $3,84 \pm 10,6 b$ & $5,54 \pm 2,34 a b$ \\
\hline A (\%) & $3,15 \pm 1,95 a$ & $2,28 \pm 5,09 a$ & $4,41 \pm 7,23 \mathrm{a}$ & $3,96 \pm 4,23 a$ & $2,16 \pm 3,04 a$ \\
\hline $\mathrm{DE}_{2}(\%)$ & $29,21 \pm 6,83 b$ & $30,67 \pm 5,44 b$ & $41,89 \pm 8,56 a$ & $36,54 \pm 7,71 \mathrm{ab}$ & $35,06 \pm 9,82 \mathrm{ab}$ \\
\hline
\end{tabular}

Médias seguidas pela mesma letra na linha não diferem (P>0,05) entre si pelo teste Tukey; DP - degradabilidade potencial; B - fração potencialmente degradável; C - taxa de degradação da fração potencialmente degradável; A - fração solúvel; $\mathrm{DE}_{2}$ - degradabilidade efetiva para as taxas de passagem de $2 \% /$ hora; $\mathrm{DE}{ }_{5}$ - degradabilidade efetiva para as taxas de passagem de $5 \% /$ hora.

Tabela 4 - Degradabilidade da proteína bruta da dieta de ovinos em pastejo na caatinga no sertão de Pernambuco em diversos meses de coleta

\begin{tabular}{|c|c|c|c|c|c|}
\hline \multirow[t]{2}{*}{ Parâmetro } & \multicolumn{5}{|c|}{ Mês } \\
\hline & Novembro & Janeiro & Março & Maio & Julho \\
\hline $\mathrm{DP}^{1}(\%)$ & $62,13 \pm 8,21 b$ & $75,74 \pm 6,47 a$ & $77,24 \pm 6,56 a$ & $71,27 \pm 9,72 a b$ & $63,67 \pm 11,27 b$ \\
\hline $\mathrm{B}^{2}(\%)$ & $42,03 \pm 7,20 \mathrm{bc}$ & $44,25 \pm 8,70 b$ & $56,09 \pm 10,31 \mathrm{a}$ & $49,54 \pm 8,28 a b$ & $35,44 \pm 11,20 c$ \\
\hline $\mathrm{C}^{3}(\% / \mathrm{h})$ & $14,36 \pm 5,14 a$ & $13,97 \pm 19,98 \mathrm{a}$ & $8,02 \pm 1,64 a$ & $7,19 \pm 3,00 \mathrm{a}$ & $5,37 \pm 1,76 a$ \\
\hline $\mathrm{A}^{4}(\%)$ & $20,21 \pm 10,50 b$ & $31,49 \pm 10,83 a$ & $21,15 \pm 10,56 a b$ & $21,51 \pm 9,57 \mathrm{ab}$ & $28,71 \pm 10,68 a b$ \\
\hline $\mathrm{DE}_{2}{ }^{5}(\%)$ & $56,78 \pm 8,42$ bc & $67,49 \pm 8,18 \mathrm{a}$ & $65,85 \pm 6,48 a b$ & $55,84 \pm 10,00 a$ & $56,46 \pm 9,91 c$ \\
\hline
\end{tabular}

Médias seguidas pela mesma letra na linha não diferem (P>0,05) entre si pelo teste Tukey; ${ }^{1}$ degradabilidade potencial; ${ }^{2}$ fração potencialmente degradável; ${ }^{3}$ taxa de degradação da fração potencialmente degradável; ${ }^{4}$ fração solúvel; ${ }^{5}$ degradabilidade efetiva para as taxas de passagem de $2 \% /$ hora; ${ }^{6}$ degradabilidade efetiva para as taxas de passagem de $5 \% /$ hora.

área de caatinga durante a época chuvosa, observaram DIVMS de 43,93 a 31,89\% e teores de NDT de 38,54 a 38,10\% durante o período chuvoso.

O período de colheita das amostras teve efeito significativo $(\mathrm{P}<0,05)$ sobre a degradabilidade potencial das frações B e C e sobre a degrabilidade efetiva da fibra em detergente neutro a 2 e 5\%/hora (Tabela 3). Esse efeito possivelmente esteve relacionado às mudanças na composição botânica e química da vegetação ao longo do período experimental, afetando as espécies presentes na área, e às partes da planta que estariam disponíveis à seleção dos animais para composição de sua dieta.

Pode-se associar o efeito da variação na degradabilidade potencial e na degradabilidade efetiva a 2 e $5 \%$ /hora da FDN à proporção dos tecidos que compõem a anatomia das plantas, que possuem taxa e extensão de digestão diferenciada. Neste sentido, Paciullo (2002) afirmou que a lenta ou digestão parcial de alguns tecidos, como a epiderme e a bainha parenquimática dos feixes, advém principalmente do arranjo adensado de suas células e da elevada espessura das paredes celulares que, geralmente, apresentam-se lignificadas. São escassos os trabalhos sobre anatomia de forrageiras nativas da caatinga.
Foi observada interação hora $\times$ período de coleta sobre a degradabilidade potencial e na degradabilidade efetiva a 2 e $5 \% /$ hora da FDN $(\mathrm{P}<0,05)$, que pode estar associada às plantas disponíveis na pastagem e suas diferentes frações (folha, caule, fruto, semente ou flor), bem como à seletividade dos animais no ato do pastejo.

Houve interação tipo de fístula $\times$ hora de coleta $(\mathrm{P}<0,05)$ sobre a fração (B) da fibra em detergente neutro. Este efeito pode estar associado ao material recuperado oriundo de cada fístula, à seleção do animal ao longo do dia por determinadas partes da planta e ao tempo de pastejo. Ressalta-se que os animais no ato do pastejo tinham preferência por determinadas áreas, ocorrendo assim "ilhas de pastejo” dentro da área experimental.

Dornelas (2003), trabalhando com caprinos e incubação dos fenos de jureminha e feijão-bravo, obteve valores de 43,52 e 48,82\% para a degradabilidade potencial; 43,52 e 48,82\% para a fração potencialmente degradável; 4,32 e 4,94\%/hora para a taxa de degradação da fração potencialmente degradável; 0,0 e 0,0\% para a fração solúvel; 27,36 e $34,19 \%$ e 18,21 e $23,81 \%$ para a degradabilidade efetiva a 2 e $5 \% /$ hora, respectivamente da fibra em detergente neutro. 
Foi observado efeito significativo do período de coleta $(\mathrm{P}<0,05)$ sobre a degradabilidade potencial, fração $\mathrm{B}$, fração A e degradabilidade efetiva a 2 e $5 \%$ /hora da proteína bruta (Tabela 4). O efeito do período de coleta está associado à variação do teor de proteína ao longo do período experimental (Tabela 1), de forma que a disponibilidade da proteína pode ter diferido entre as frações. Compostos indisponíveis entre a fração protéica e os carboidratos ou compostos secundários existentes nas plantas, como é o caso dos taninos, podem ter sido formados.

Kohn \& Allen (1995) relataram que a degradação ruminal da proteína bruta depende da taxa de degradação individual de cada proteína no rúmen e de sua taxa de passagem e esses fatores podem ser influenciados pela associação da proteína com outros componentes do alimento e pela disponibilidade de ligações peptídicas ao ataque enzimático.

Foi observada interação período $\times$ hora de coleta $(\mathrm{P}<0,05)$ sobre a fração B e sobre a fração A da proteína bruta. Esta interação pode ser explicada pela variação do teor de proteína ao longo do período, bem como pela parte da planta que foi selecionada pelo animal.

Houve efeito significativo $(\mathrm{P}<0,05)$ da interação tipo de fístula $\times$ hora de coleta sobre a degradabilidade potencial, fração solúvel e a degradabilidade efetiva a 2 e 5\%/hora da proteína bruta. Essa interação pode estar associada à diferença na recuperação da amostra entre os animais com fístula esofágica e ruminal, que resultou em amostras com composição química e botânica diferentes, em virtude da participação de componentes da dieta que só puderam ser recuperados nas amostras de extrusa de origem ruminal por se tratarem de frutos, sementes ou partes destes que não passaram pela fístula esofágica.

Dornelas (2003) avaliou a degradabilidade potencial (\%), a fração potencialmente degradável (\%), a taxa de degradação da fração potencialmente degradável (\%/hora), fração solúvel (\%) e degradabilidade efetiva (2 e 5\%/hora) da proteína bruta e obteve valores de 76,92; 47,87; 4,39; 29,05;61,43;51,00 e 71,84\%;37,77;5,36;34,07;61,23; e53,31\%, para os fenos de jureminha e feijão-bravo, respectivamente.

Vieira et al. (1998), utilizando caprinos da raça Moxotó, avaliaram a degradabilidade da MS, FDN e da PB do feno de três forrageiras nativas e encontraram valores de 39,92, 38,45 e $62,95 \%$ para o feno de jucá; $34,04,35,44$ e 36,75\% para o feno de mororó e 40,81, 34,42 e 27,37\% para o feno de sabiá, respectivamente.

Considerando as variações na composição química e na degradabilidade dos componentes químicos do pasto, sugere-se que em futuros trabalhos, inicialmente seja realizado o acompanhamento do comportamento animal em pastejo, determinando assim seus horários de pastejo e ruminação, para que as coletas da extrusa para determinação da dieta sejam altamente associadas aos hábitos dos animais.

\section{Conclusões}

A composição química e a degradabilidade in situ da dieta de ovinos na caatinga é influenciada pelo mês de avaliação. Embora a dieta possua alto percentual de proteína bruta, parte dessa proteína está indisponível para o animal por estar ligada à fibra em detergente ácido. A dieta dos ovinos em área de caatinga apresentou baixa degradabili-dade in situ da matéria seca, fibra em detergente neutro e proteína bruta. A fístula no rúmen, em comparação à fístula de esôfago, permite melhor avaliação da dieta de ovinos na caatinga, pois possibilita a recuperação total da extrusa.

\section{Literatura Citada}

AGRICULTURAL AND FOOD RESEARCH COUNCIL - AFRC. Energy and protein requirements of ruminants. Wallingford: CAB International, 1993. 159p.

ARAUJO FILHO, J.A.; CARVALHO, F.C.; SILVA, N.L. Fenología y valor nutritivo de follajes de algunas especies forrajeras de la Caatinga. Agroforestería en las Américas, v.9, n.33-34, p.3337, 2002.

ARAUJO FILHO, J.A.; GADELHA, J.A.; LEITE, E.R. et al. Composição botânica e química da dieta de ovinos e caprinos em pastoreio combinado na região de Inhamuns, Ceará. Revista Brasileira de Zootecnia, v.25, n.3, p.383-395, 1996.

BATISTA, A.M.V.; MATTOS, C.W. Aspectos nutricionais de pequenos ruminantes no semi-árido. In: SIMPÓSIO INTERNACIONAL DE CONSERVAÇÃO DE RECURSOS GENÉTICOS, 1., 2004, Recife. Anais... Recife: 2004. p.75-82.

BEELEN, P.M.G.; BERCHIELLI, T.T.; BUDDINGTON, R. et al. Efeito dos taninos condensados de forrageiras nativas do semi-árido nordestino sobre o crescimento e atividade celulolítica de Ruminococcus flavefaciens FD1. Arquivo Brasileiro de Medicina Veterinária e Zootecnia, v.58, n.5, p.910-917, 2006.

CARVALHO FILHO, O.M.; SALVIANO, L.M. Evidências de ação inibidora da jurema-preta na fermentação "in vitro" de gramíneas forrageiras. Petrolina: EMBRAPA/CPATSA, 1982. 15p. (Circular Técnica, 11).

DORNELAS, C.S.M. Cinética ruminal em caprinos de forrageiras nativas. 2003. 63f. Dissertação (Mestrado em Zootecnia) - Universidade Federal da Paraíba, Areia, 2003.

FAO/IAEA. Quantification of tannins in tree foliage. Rome: FAO/IAEA Division of Nuclear Techniques in Food and Agriculture. 2000. p.1-25. (Working Document).

GONZAGA NETO, S.; BATISTA, A.M.V.; CARVALHO, F.F.R. et al. Composição química, consumo e digestibilidae "in vivo" de dietas com diferentes níveis de feno de catingueira (Caesalpinea bracteosa) fornecida para ovinos Morada Nova. Revista Brasileira de Zootecnia, v.30, n.2, p.553562, 2001.

GONZAGA NETO, S. Consumo, digestibilidade e degradabilidade de dietas com diferentes níveis de feno de catingueira (Caesalpinea bracteosa), em ovinos e bovinos. 1999. 44f. 
Dissertação (Mestrado em Zootecnia) - Universidade Federal Rural de Pernambuco, Recife, 1999.

HALL, M.B. Recentes avanços em carboidratos não-fibrosos na nutrição de vacas leiteiras. In: SIMLEITE, 2., 2001, Lavras. Anais... Lavras: 2001. p.149-159.

KOHN, R.A.; ALLEN, M.S. Prediction of protein degradation of forages solubility fractions. Journal of Dairy Science, v.78, n.8, p.1774-1788, 1995.

LICITRA G.; HERNANDEZ T.M.; Van SOEST P.J. Standardization of procedures for nitrogen fractionation of ruminant feeds. Animal Feed Science and Technology, v.57, n.4, p.347-358, 1996.

LIMA, M.A.; FERNANDES, A.P.M.; SILVA, M.A. et al. Avaliação de forragens nativas e cultivadas em área de caatinga no sertão de Pernambuco. Revista Brasileira de Zootecnia, v.16, n.6, p.517-531, 1987.

MARQUES, C.A.T.; BATISTA, A.M.V. Avaliação da composição química e da degradabilidade de sabiá (Mimosa caesalpiniifolia Benth) em diferentes épocas do ano. In: CONGRESSO DE INICIAÇÃO CIENTÍFICA, 7., 1998, Recife. Anais... Recife: Universidade Federal Rural de Pernambuco, 1998. p.247.

MOREIRA, J.N.; LIRA, M.A.; SANTOS, M.V.F. et al. Caracterização da vegetação de Caatinga e da dieta de novilhos no Sertão de Pernambuco. Pesquisa Agropecuária Brasileira, v.41, n.11, p.1643-1651, 2006.

ORSKOV, E.R.; McDONALD, I. The estimation of protein degradability in the rumen from incubation measurements weighted according to rate of passage. Journal of Agriculture Science, v.92, p.499-453, 1979.

PACIULLO, D.S.C. Características anatômicas relacionadas ao valor nutritivo de gramíneas forrageiras. Ciência Rural, v.32, n.2, p.357-364, 2002.

PIMENTEL, J.C.N.; ARAÚJO FILHO, J.A.; NASCIMENTO JR., D. et al. Composição botânica da dieta de ovinos em área de caatinga raleada no sertão do Ceará. Revista Brasileira de Zootecnia, v.21, n.2, p.211-241, 1992.
SAMPAIO, E.V.S.B.; PAREYN, F.G.C.; FIGUEIRÔA, J.M. et al. Espécies da flora Nordestina de importância econômica potencial. Recife: Associação Plantas do Nordeste, 2005. 331p.

SANTOS, G.R.A. Caracterização da vegetação e da dieta de ovinos em área de caatinga no sertão de Pernambuco. 2007. 111f. Tese (Doutorado em Zootecnia) - Universidade Federal Rural de Pernambuco, Recife, 2007.

STATISTICAL ANALYSIS SYSTEM - SAS. SAS/STAT 9.1: user's guide. Cary: SAS Institute SAS, 2004. v.3, 675p.

SILVA, D.J.; QUEIROZ, A.C. Análise de alimentos (métodos químicos e biológicos). Viçosa, MG: Editora UFV, 2002. 235p.

SNIFFEN, C.J.; O’CONNOR, J.D.; Van SOEST, P.J. et al A net carbohydrate and optimal protein system for evaluating cattle diets. II. Carbohydrate and protein availability. Journal of Animal Science, v.70, p.3562-3577, 1992.

Van SOEST, P.J. Nutritional ecology of the ruminant. New York: Cornell University Press, 1994. 498p.

Van SOEST, P.J.; ROBERTSON, J.B.; LEWIS, B.A. Methods for dietary fiber, neutral detergent fiber, and nonstarch polysaccharides in relation to animal nutrition. Journal of Dairy Science, v.74, p.3583-3597, 1991.

VASCONCELOS, M.A.B.; FERNANDES, F.D.; OLIVEIRA, E.R. et al. Composição química da dieta de caprinos no semi-árido do Estado do Ceará. In: REUNIÃO ANUAL DA SOCIEDADE BRASILEIRA DE ZOOTECNIA, 33., 1996, Fortaleza. Anais... Fortaleza: Sociedade Brasileira de Zootecnia, 1996. p.265-266.

VASCONCELOS, V.R.; RESENDE, K.T.; PIMENTEL, J.C.M. et al. Degradação potencial e efetiva de forrageiras do semi-árido brasileiro em caprinos. In: REUNIÃO ANUAL DA SOCIEDADE BRASILEIRA DE ZOOTECNIA, 34., 1997, Juiz de fora. Anais... Juiz de Fora: Sociedade Brasileira de Zootecnia, 1997. p.49-51.

VIEIRA, E.L.; SILVA, A.M.A.; GERMANO, R. et al. Valor nutritivo do feno de espécies lenhosas da caatinga. In: REUNIÃO ANUAL DA SOCIEDADE BRASILEIRA DE ZOOTECNIA, 35., 1998, Botucatu. Anais... Botucatu: Sociedade Brasileira de Zootecnia, 1998. v.2, p.227-232. 